\title{
ORIENTASI PENDIDIKAN PESANTREN SALAFIYAH: Studi Kasus Pesantren Benda Kerep Cirebon
}

\author{
Oleh: Ta'rif \\ Peneliti Puslitbang Pendidikan Agama dan Keagamaan \\ Jl. MH Thamrin No. 06 Jakarta Pusat \\ fajarhm@yahoo.co.id
}

\begin{abstract}
Pesantren is the oldest educational institution in Indonesia, which is also a subculture that has been fused and colored to the patterns of social life of religious affairs, nation and state in Indonesia. Over the time, many pesantrens are transforming themselves. The teaching methods, culture and even pesantren orientation are shifting together with the flow of changing times. The presence of these changes is expected to continue to address the needs of schools and the increasingly complex problems of the people. However, unlike the case of Benda Kerep Islamic Boarding School, a pesantren located at Benda Kerep Block, Argasunya Village, Harja Mukti Sub-district, Cirebon City, West Java. In the middle of the swift current of changes, this pesantren remains committed and defended the noble values and the past traditions. Changes hardly occur either in social, cultural, religious, and learning method aspects. External system changes do not change the existing education traditions and systems. Even the caregivers, using the legitimacy of the pesantren's founders try desperately to maintain the traditions as an advantage and uniqueness.
\end{abstract}

Keywords: Pesantren, Tradition, Education Orientation

\begin{abstract}
Abstrak
Pesantren merupakan lembaga pendidikan tertua di Indonesia yang juga merupakan subkultur yang telah menyatu dan mewarnai corak kehidupan sosial keagamaan, berbangsa dan bernegara di Indonesia. Seiring dengan berjalannya waktu, banyak pesantren yang kemudian mengalami transformasi diri. Metode pengajaran, kultur, bahkan orientasi pesantren bergeser mengikuti arus perubahan zaman. Melalui perubahan ini diharapkan kehadiran pesantren dapat senantiasa menjawab kebutuhan dan problematika umat yang semakin kompleks. Namun demikian, berbeda halnya dengan Pondok Pesantren Benda Kerep, sebuah pesantren yang berlokasi di Blok Benda Kerep Desa Argasunya, Kecamatan Harja Mukti - Kota Cirebon Jawa Barat. Di tengah derasnya arus perubahan, pesantren ini tetap istiqamah mempertahankan nilai-nilai luhur dan tradisi masa lalu. Perubahan hampir tidak terjadi baik dalam kehidupan sosial, kultural keagamaan, serta metode pembelajarannya. Perubahan sistem di luar tidak serta merubah tradisi dan sistem pendidikan yang ada. Bahkan para pengasuh, dengan menggunakan legitimasi wasiat para pendiri pesantren, berupaya sekuat tenaga mempertahankan tradisi tersebut sebagai sebuah kelebihan dan keunikan tersendiri.
\end{abstract}

Kata Kunci: Pesantren, Tradisi, Orientasi Pendidikan

Naskah diterima 20 April 2012, revisi pertama 30 Mei 2012, revisi kedua 15 Mei 2012 dan revisi akhir 2012 


\section{PENDAHULUAN}

Dunia pesantren di Indonesia tampaknya telah mengalami perubahan secara signifikan. Perubahan tersebut bukan hanya bersifat kuantitatif yang terlihat dari jumlah kelembagaan dan santri yang selalu meningkat, tetapi juga perubahan yang bersifat kualitatif antara lain perubahan visi dan misi, program pendidikan/kurikulum, pola kepemimpinan, adaptasi sistem pendidikan di luarnya dan seterusnya. Pengaruh ideologi dan faham keagamaan serta jaringan yang terbangun dengan dunia luar, sampai kepada peran pesantren yang semakin luas (wider mandate). Semuanya sangat mempengaruhi orientasi pendidikan pesantren. Tipologi pesantren Salafiyah, Kombinasi, Ashriyah, atau Pesantren Tradisional dan Pesantren Modern tampaknya tidak memadai lagi untuk melihat dinamika dan perkembangan pesantren yang ada saat ini.

Perubahan orientasi pendidikan sebuah pesantren pada umumnya berlangsung secara adaptif gradual, penuh kehatihatian agar pesantren tetap menjalankan peran kepesantrenannya, menjaga tradisi dan identitas kultur keagamaan (salafiyah), tetapi juga tetap membuka peran-peran perubahan sesuai dengan perubahan dan kebutuhan umat. Prinsip "Almuhafadzotu ala al qadimi ash shalih, wal akhdzu bi al-jadid al ashlah" yaitu melestarikan yang lama yang masih baik dan mengambil yang baru yang lebih baik hingga sekarang masih berlaku di kalangan masyarakat pesantren dalam melakukan adaptasi secara cerdas dan arif terhadap tuntutan sistem di luarnya.

Perkembangan linear pada pesantren yang pada awalnya pesantren lebih memerankan diri sebagai lembaga keagamaan dan dakwah tempat para santri belajar dan mendalami ilmu-ilmu agama Islam "tafaqquh fiddin" yang berbasis kitab kuning, tanpa mengharapkan ijazah atau (civil effect), kemudian berkembang menjadi pusat-pusat pendidikan dan pengembangan masyarakat. Sistem pendidikan yang semula lebih bersifat nonformal, ngaji dengan metode bandongan, wetonan dan sorogan berkembang menjadi pusat-pusat pendidikan baik melalui madrasah, sekolah umum, mulai dari tingkat pra sekolah, pendidikan dasar, menengah sampai pendidikan tinggi. Banyak pesantren mengembangkan berbagai jenis keterampilan, agribisnis, perdagangan dan jasa serta pengembangan masyarakat yang lebih luas. Sebagian pengamat berpendapat pendidikan pesantren menjalankan peran-peran seperti"holding company".

Namun demikian, ada saja pesantren yang - karena berbagai faktor - cenderung mempertahankan dan melanggengkan tradisi masa lalu dan terjebak dalam romantisme dan belenggu sejarah. Sistem pendidikannya lebih menampakkan wajah pendidikan periode masa lalu dengan segala keunikannya, dan sangat berbeda dengan sistem pendidikan mainstream pada umumnya. Uniknya, dengan keunikan dan peran pelanggengannya ini justru ia memperoleh tempat tersendiri di kalangan masyarakat dan menjadi faktor pesantren tersebut mampu mempertahankan keberadannya.

Pesantren Salafiyah Benda Kerep (PBK) yang berlokasi di Blok Benda Kerep Desa Argasunya, Kecamatan Harja Mukti Kota Cirebon Jawa Barat adalah salah satu pesantren yang mempertahankan tradisi masa lalu sebagaimana disinggung di atas. Pesantren Benda Kerep cenderung sangat hati-hati terhadap modernitas dengan melakukan filterirasi secara selektif menerima perubahan dengan tetap melestarikan kearifan budaya lokal (salafiyah) terutama dalam konsep pendidikan dan pemberdayaan masyarakat. Karena ketatnya proses filterisasi yang dilakukan, maka dalam pandangan sepintas Pesantren Benda Kerep cenderung ditempatkan sebagai pesantren "tradisional" yang lebih berperan sebagai bentuk pelanggengan dibandingkan dengan peran perubahan.

Studi pesantren ini dianggap penting, setidaknya karena kemampuan survive- 
nya di tengah hadirnya berbagai lembaga pendidikan formal di lingkungan sekitarnya yang ijazahnya mempunyai civic effect terhadap dunia kerja dan studi lanjut. Ketahanan hidup PBK ini sebagai lembaga pendidikan Islam Tradisional, ternyata berbeda dengan kebanyakan lembaga pendidikan tradisonal lainnya. Seperti digambarkan Steenbrink ${ }^{1}$ ketika diperkenalkan lembaga pendidikan yang lebih teratur dan modern, lembaga pendidikan tradisional ternyata tidak laku dan banyak yang ditinggalkan masyarakat. Misalnya lembaga pendidikan Surau di Minagkabau, bahkan surau sekarang sudah punah dan ketika didirikan lembaga pendidikan Islam di sana, tidak lagi menggunakan Surau tetapi pesantren. Temuan Steenbrink ini diperkuat oleh Kesimpulan Azyumardi Azra, sejak dilancarkan perubahan atau modernisasi pendidikan Islam di berbagai kawasan dunia Muslim, tidak banyak lembaga pendidikan tradisional yang mampu bertahan, banyak dan lenyap setelah tegusur oleh ekspansi sistem pendidikan umum seperti kasus $M e-$ drese di Turki, dan Madrasah di Mesir. ${ }^{2}$

Berdasarkan latar belakang di atas, tulisan ini akan mengungkap tentang bagaimana orientasi pendidikan Pesantren Benda Kerep Cirebon di tengah perubahan yang terjadi? Dan bagaimana bentuk-bentuk pelestarian dan perubahan pendidikan salafiyah di Pesantren Benda Kerep?

\section{METODOLOGI PENELITIAN}

Penelitian ini dilakukan secara langsung (flied research) pada Pondok Pesantren Benda Kerep Kelurahan Argasunya Kecamatan Harjamukti Kota Cirebon dengan menggunakan pendekatan kualitatif. Pengumpulan data banyak menggunakan

${ }^{1}$ Karel A. Steenbrink. 1986. Sekolah, Pesantren, Madrasah, Sekolah: Pendidikan Islam dalam Kurun Moderen. Jakarta: LP3ES.

${ }^{2}$ Azyumardi Azra. 2001. Pendidikan Islam: Tradisi dan Modernisasi Menuju Millenium Baru. Jakarta: Kalimah, h. 96 pengamatan mendalam terhadap setiap fenomena yang ditemui. Setiap data dan informasi dilihat sebagai suatu kesatuan yang memiliki keterkaitan satu dengan yang lain. Adapun teknik analisis data dalam penelitian ini menggunakan analisis deskriptif yang bersifat deskriptif yang bertujuan menggambarkan keadaan atau status fenomena dengan tidak menggunakan hipotesis tertentu. Sedangkan teknik pengumpulan data yang dipergunakan adalah wawancara mendalam, observasi partisipatif dan studi dokumentasi serta diskusi.

Wawancara mendalam digunakan untuk menggali data dan informasi dari pengasuh pesantren, ustadz, santri dan alumni, Kandepag Kota Cirebon, Kelurahan Argasunya, masyarakat sekitar serta melakukan klarifikasi (tabayyun) terhadap pihak yang berkompeten terhadap beberapa temuan lapangan yang memerlukan klarifikasi dan penjelasan lebih lanjut. Pengamatan dilakukan terhadap penyelenggaraan pendidikan, lingkungan sosial, lingkungan kultural, pola interaksi antar warga komunitas pesantren, maupun dengan masyarakat luar pesantren. Pengamatan terlibat juga dilakukan terhadap proses belajar mengajar di kelas, salat berjamaah, pertemuan dengan guru, kehidupan santri di asrama, interaksi antar santri, santri dengan guru, suasana makan bersama, kerja bakti membersihkan halaman asrama, merawat kebersihan kamar, mencuci pakaian, suasana ruang belajar, dan seterusnya. Sedangkan studi dokumen dilakukan terhadap semua sumber dokumen yang dapat memberikan data dan informasi Pesantren Benda Kerep.

\section{KERANGKA TEORITIK}

Awalnya, pesantren merupakan lembaga pendidikan Islam tradisional (salafy) yang fungsi dan tujuannya adalah sebagai tempat untuk mengembangkan syi'ar islamiyah. Maju atau mundurnya lembaga ini sangat bergantung atau dipengaruhi 
kiyainya, dan hanya dikenal di kalangan atau lingkungan setempat. Keberadaan pesantren saat itu bersifat tertutup dan perannya pun masih terbatas pada persoalan keagamaan bagi masyarakat lingkungannya saja. Perkembangan berikutnya, beberapa pesantren tertentu yang dipimpin kiyaicendekiawan muslim mulai memperoleh perhatian masyarakat luas sejak awal abad ke-20. Sejak itu, pondok pesantren menjadi suatu sistem atau lembaga pendidikan terbuka yang mau menerima input dan menyesuasikan diri dengan perkembangan dan keinginan masyarakat luas; perannya pun tidak hanya dalam bentuk keagamaan, melainkan juga masalah-masalah sosial lainnya. Inilah yang dimaksud Mastuhu bahwa, "pondok pesantren adalah lembaga pendidikan Islam yang bercirikan grass root people yang telah tumbuh dan berkembang di Nusantara sejak 300-400 tahun yang lalu" ${ }^{\prime \prime}$.

Implikasi dari perubahan ini adalah, fungsi lembaga ini berubah dan melengkapi dirinya dengan perlengkapan yang ada pada lembaga pendidikan sekolah pada umumnya, yaitu bentuk kelembagaan yang menerapkan sistem kelas, kurikulum dan metode pengajaran yang tidak hanya ala tradisional yakni sorogan, bandongan dan halaqah. Kenyataan ini menggambarkan bahwa, usaha dan kegiatan yang dilakukan pondok pesantren secara garis besar dapat dibedakan atas dua fungsi pelayanan yaitu: pelayanan kepada santri dan pelayanan kepada masyarakat. ${ }^{4}$ Dalam bentuk pelayanan pertama, pesantren menyajikan beberapa sarana bagi perkembangan para santrinya; sedangkan bentuk pelayanan kedua, pesantren berusaha mewujudkan masyarakat sesuai dengan perkembangan dan kemampuan yang ada.

${ }^{3}$ Mastuhu. 1994. Dinamika Sistem Pendidikan Peantren: suatu Kajian tentang Unsur dan Nilai Sistem Pendidikan Pesantren. Jakarta: INIS, h. 21

${ }^{4}$ M. Dawam Raharjo (ed.). 1985. Pergulatan Pesaantren; Membangun dari Bawah. Jakarta: P3M, h. 16
Pernyataan di atas menunjukkan bahwa, pondok pesantren adalah lembaga pendidikan dan lembaga sosial yang selalu adaptif terhadap perubahan dan perkembangan yang terjadi di lingkungannya. Sifat adaptif itu diwujudkan dalam bentuk penerapan kurikulum yang diperlukan untuk mengantisipasi tuntutan dan perkembangan. Manurut Cuban ada tiga dasar keyakinan yang kondusif untuk dijadikan sebagai landasan akan pentingnya memperhatikan sifat adaptif kurikulum terhadap perubahan yaitu: 1) perubahan yang terjadi sifatnya positif, 2) perubahan yang terjadi di lingkungan sekolah cenderung sifatnya terus menerus (kontinue) dan 3) perlunya usaha untuk menyempurnakan rencana-rencana yang disusun oleh lembaga atau pendidik, karena terjadinya proses adopsi terhadap suatu inovasi.

Berpatokan pada ketiga dasar keyakinan di atas maka dapat diyakini bahwa, perubahan yang terjadi di pondok pesantren sangat penting artinya karena dapat mempengaruhi kurikulumnya. Selama ini, antara pondok pesantren dengan masyarakat dalam pemahaman terhadap suatu nilai (ketetapan sikap dan perilaku) terdapat perbedaan yang mendasar. Pondok pesantren dalam pemahaman terhadap nilai-nilai keagamaan lebih bersifat tekstual, sedangkan masyarakat lebih bersifat kontekstual. Pemahaman secara kontekstual yang dipilih masyarakat, akan melahirkan semangat kreatif-inovatif sesuai dengan persoalan yang sedang berkembang. Di samping itu, pemahaman secara kontekstual juga dapat memberikan motivasi yang kuat bagi seseorang untuk melakukan interpretasi atau reinterpretasi terhadap suatu nilai yang bersifat tektual untuk mengadaptasi persoalan-persoalan yang muncul dan berkembang,

Pola pemahaman pertama (pemahaman terhadap nilai secara tekstual) biasanya dilakukan oleh beberapa pesantren tradisional, sedangkan pesantren yang tengah berusaha menerapkan kurikulumnya sesuai 
dengan keinginan masyarakat, cenderung menggunakan pola kedua (pemahaman secara kontekstual). Perkembangan dengan pola kedua ini cukup kondusif untuk menopang proses inovasi, apalagi jika dikaitkan dengan usaha-usaha untuk membuktikan kebaikan dari inovasi itu dalam sistem kehidupan masyarakat lingkungan pondok pesantren khususnya.

Untuk menerapkan pola kedua, sangat ditentukan oleh seorang pemimpin pondok pesantren yang memiliki ilmu pengetahuan keagamaan yang luas, memahami betul tentang kurikulum pendidikan sekolah juga diterima oleh masyarakat terutama karena kewibawaan dan kesalehannya. Pemimpin pondok pesantren dimaksud adalah kiyai yang memiliki visi dan misi yang jelas dalam mengembangkan sistem pendidikan Islam di pondok pesantren yang dipimpinnya. Salah satu visinya yang prospektif dan memenuhi tuntutan masyarakat adalah memadukan dua sistem pendidikan yang berbeda yaitu sistem pendidikan sekolah dan sistem pendidikan pondok pesantren. Misi dari penggabungan kedua sistem pendidikan itu, memberikan arah dan tujuan jangka panjang kepada para santrinya agar memperoleh dua ilmu pengetahuan sekaligus dalam satu saat yang bersamaan. Kedua ilmu pengetahuan dimaksud adalah ilmu pengetahuan keagamaan yang diperolehnya melalui lembaga pendidikan pondok pesantren dan ilmu pengetahuan umum atau keterampilan yang diperolehnya melalui lembaga pendidikan sekolah yang dimasukinya.

\section{HASIL DAN PEMBAHASAN}

\section{Profil Pesantren Benda Kerep}

Pesantren Benda Kerep terletak Kampung Benda Kerap, sebuah kampung di pinggiran Kota Cirebon, tepatnya di Kelurahan Argasunya, Kecamatan Harjamukti, Kota Cirebon, sekitar $10 \mathrm{~km}$ arah selatan dari pusat Kota Cirebon. Secara geografis, posisi Benda Kerep berada pada posisi 10833 Bujur Timur dan 61 Lintang Selatan. Bentang alamnya merupakan dataran tinggi daerah Cirebon dengan luas tanah 33 hektar. Kebanyakan warga kampung ini bekerja sebagai petani, baik penggarap maupun pemilik di ladang dan di sawah. Sedangkan sebagian lainnya bekerja sebagai buruh pasir, pedagang, tukang ojek dan yang lainnya.

Menelusuri sejarah pendirian Pesantren Benda Kerep (PBK), tidak banyak bahkan nyaris tidak ditemukan literatur asli yang ditulis oleh keturunan pendiri Pesantren Benda Kerep. Menurut informasi dari Kyai Miftah yang merupakan salah satu keturunan generasi ke-4 dari pendiri Pesantren Benda Kerep, hal ini dikarenakan adanya wasiat dari pendiri yang wantiwanti melarang sejarah berdirinya Benda Kerep khususnya sejarah pendirinya untuk di dokumentasikan. ${ }^{5}$

Wasiat tersebut setidaknya memberikan dua pesan moral yang berharga. Pertama, diharapkan kepada keturunan dari pendiri Pesantren Benda Kerep untuk senantiasa menghafal sejarah dalam kerangka menjaga dan melestarikan kearifan nilai sebuah budaya khususnya di Benda Kerep. Kedua, untuk menghindari adanya kultus individu oleh para keturunan dan masyarakat terhadap pendiri dari Pesantren Benda Kerep.

Sejarah panjang pendirian Pesantren Benda Kerep dirintis oleh seorang ulama kharismatik nan tawadhu', yakni KH. Sholeh yang lebih familiar dengan sebutan Mbah Sholeh. Mbah Sholeh yang merupakan satu periode dengan Hadhratussyaikh $\mathrm{KH}$. Hasyim Asyari, adalah keturunan dari Keraton Cirebon, generasi ke-13 dari Syekh Syarif Hidayatullah (Sunan Gunung Djati). Dalam rangka mencari tempat yang dianggap representatif untuk pengembangan syiar Islam, Mbah Sholeh bersama Kyai

${ }^{5}$ Wawancara dengan K. Miftah, Tanggal 21 September 2011. 
Anwarudin (pesantren Buntet) mendapatkan ilham untuk melakukan "Babad Alas" terhadap wilayah yang terisolasi (belum terjamah manusia) yang sekarang dikenal dengan wilayah Benda Kerep.

Nama Benda Kerep yang sekarang menjadi sebutan wilayah tersebut sekaligus menjadi nama bagi lembaga Pondok Pesantren, sebelumnya memiliki sebutan nama yaitu; Karang Pawitan dan Cimeuwuh. Secara etimologis, penyebutan Karang Pawitan bermakna tanah "Tanah Pertama/ Awal" karena Mbah Sholeh sebagai orang pertama yang dapat menjamah kawasan tersebut. Kemudian sebutan Cimeuweuh berasal dari bahasa Sunda terdiri dari kata; cai (air) dan meuweuh (hilang/lenyap). Menurut cerita mitos yang masih dipercaya warga sekitar dan informasi Kyai Miftah (salah satu generasi ke-4 dari Mbah Sholeh), konon waktu itu siapa saja yang mencoba masuk daerah tersebut maka akan hilang tidak pernah kembali lagi karena dibawa oleh mahluk ghaib yang banyak menghuni wilayah tersebut.

Selanjutnya setelah Mbah Sholeh menaklukan daerah Cimeuweuh, beliau menggantinya dengan sebutan Benda Kerep, $i$ 'tibar terhadap kondisi wilayah tersebut yang banyak ditumbuhi pohon benda (semacam sukun) dan banyaknya pohon benda yang tumbuh rapat (Jawa: kerep) maka wilayah tersebut dikenal hingga saat ini sebagai Benda Kerep. Secara geografis, wilayah Benda Kerep lebar dengan luas sekitar 30 Hektar yang diisolasi oleh sungai masih termasuk tanah milik Keraton Kanoman Cirebon. Atas dedikasi Mbah Sholeh mengembangkan wilayah tersebut sebagai pusat syiar Islam, Sultan Zulkarnaen (Raja Kraton Kanoman waktu itu) memberikan hibah wilayah tersebut kepada Mbah Sholeh.

Berita Mbah Sholeh, sebagai ulama yang kharismatik, tawadhu', memiliki wawasaan keagamaan mendalam, mempunyai kesaktian, dan berakhlak sangat mulia yang telah berhasil menaklukkan tanah Cimeuweuh mengundang banyak orang dari berbagai daerah untuk belajar menimba ilmu dan akhlak kepada beliau. Karena semakin banyaknya masyarakat yang ingin belajar kepada Mbah Soleh, maka beliau dibantu dengan beberapa murid membangun Pondok Pesantren Benda Kerep dengan sangat sederhana. Perjuangan Mbah Sholeh dalam mengajarkan ilmu agama dan akhlak kepada masyarakat melaui Pesantren Benda Kerep, masih tetap istiqamah diteruskan oleh keturunan-keturunan hingga saat ini.

Mbah Shaleh memilki tiga orang putra dan putri, yaitu pertama adalah Embah Muslim atau K. Muslim, putra keduanya adalah K. Abu Bakar dan yang ketiga adalah Nyai Qona'ah. Dari Embah Muslim sebagai anak pertama mempunyai tujuh orang putra, sementara istri dan anak perempuan belum ditemukan keterangannya. Diantara tujuh orang putra tersebut adalah: K. Kaukab (Benda Kerep), K. Zaeni Dahlan (Benda Kerep), K. Muhtadi (Benda Kerep), K. Sayuti (Cibogo), K. Fahim (Benda Kerep), K. Fatin (Benda Kerep), dan K. Mas'ud (Benda Kerep). Sedangkan dari KH. Abu Bakar Putra kedua Embah Shaleh mempunyai dua orang putra diantaranya adalah: K. Hasan (Benda Kerep --Mertua dari K. Muhammad Nuh) dan KH. Faqih (Benda Kerep- Ayah kandung dari K. Muhammad Miftah).

\section{Kepemimpinan}

Peranan kyai, selain sebagai figur sentral juga sebagai pucuk pimpinan dalam pengambilan keputusan berkaitan dengan pesantren dan kemasyarakatan. Begitupun dengan kepemimpinan Pesantren Benda Kerep saat ini. Model kepemimpinan yang dilakukan oleh para kyai dapat digolongkan dengan "kepemimpinan kharismatik". Sebagaimana Weber menyatakan bahwa Karisma untuk menyebut suatu keadaan (sifat) dari kepribadian seseorang yang dianggap berbeda dari orang biasa dan di- 
anggap diberkati dengan kekuatan adikodrati yang melebihi kekuatan manusia biasa. Oleh karena itu, sifat kharismatik lebih merupakan anugerah Allah SWT baik melalui Mu'jizat, Karomah maupun Ma'unah kepada siapapun yang dikehendaki-Nya. Dalam konteks ini, karena kyai adalah orang yang memiliki karisma maka dengan sendirinya ia diperlakukan sebagai pemimpin dan melahirkan kewenangan yang membentuk adanya pengikut.

Pengaruh kepemimpinan kyai merupakan hal yang terlihat jelas dalam kehidupan pesantren dan masyarakat Kampung Benda Kerep. Adanya pengaruh kyai tidak terlepas dari peranan kyai yang begitu mendapat tempat dalam masyarakat. Pengaruh kyai yang begitu kuat dan luas ini telah melahirkan hubungan patron - client $^{6}$ antara kyai dengan masyarakat. Kyai bertindak sebagai patron yang berfungsi melindungi masyarakat. Dengan kekuatan ilmu yang dimilikinya, kyai dapat melindungi masyarakat, penasihat spiritual, mengatasi berbagai keresahan, keputusasaan, dan kecemasan yang dialami seorang penduduk.

Dengan mengikatkan hubungan yang kuat dengan kyai, masyarakat merasa mendapat perlindungan dan aman. Atas perlindungan itu masyarakat merasa berhutang budi kepada kyai. Kuatnya hubungan patron - client ini telah membentuk dan memperkuat tradisi masyarakat Kampung Benda Kerep. Begitu pula dalam interaksi antara kyai dengan santri, kyai menjadi figur sentral, ia menjadi teladan dan sumber

${ }^{6}$ Menurut JC Scott patronase adalah suatu kasus hubungan antar dua orang yang sebagian besar melibatkan persahabatan instrumental, dimana seseorang yang lebih tinggi kedudukan soisial ekonominya (patron) menggunakan pengaruh dan sumber daya yang dimilkinya untuk memberikan perlindungan, keuntungan atau kedua-duanya kepada orang yang lebih rendah kedudukannya (klien), yang pada gilirannya membalas pemberian tersebut dengan memberikan dukungan yang umum dan bantuan, termasuk jasa-jasa pribadi, kepada patron. Lihat dalam James C. Scott. 1993 Perlawanana Kaum Tani, terj. Budi Kusworo Dkk. Jakarta: Yayasan Obor Indonesia, h.7. nilai bagi kehidupan para santri. Karena keilmuan dan kekaramahan yang dimiliki kyai, sehingga santri akan selalu taat dan patuh terhadap petuah dan perintah kyai.

Pesantren Benda Kerep mengalami beberapa pergantian kepemimpinan mulai dari Mbah Sholeh sebagai pendiri awal, kemudian dilanjutkan oleh KH. Mbah Muslim, lalu oleh KH. Mbah Abu Bakar dan KH. Faqih merupakan generasi yang sekarang memegang tajuk kepemimpinan Pesantren Benda Kerep. Dari empat kepemimpinan yang ada, model kepemimpinan kharismatik masih menjadi ciri khas pesantren ini.

Saat ini Pondok Pesantren Benda Kerep diasuh oleh banyak kyai yang merupakan keturunan dari Mbah Sholeh, maka dalam model kepemimpinan saat ini dapat dijelaskan sebagai berikut: Pertama ; Kepemimpinan pesantren hanya bisa dipimpin oleh saudara atau keturunan utama yang merupakan keluarga pesantren. Hal ini dilakukan karena mereka berpegang untuk meneruskan amanat dan wasiat dari sesepuh pendiri pesantren (Mbah sholeh) sehingga tidak mengalami kesulitan di kemudian hari baik dalam meluruskan misi dan visi pesantren. Kedua, Masing-masing kyai di wilayah Benda Kerep memiliki santri di rumah / asrama masing-masing dan memiliki otoritas penuh terhadap konsep dan metodologi pendidikan yang diterapkan terhadap santri masing-masing dengan tetap berpegang teguh kepada grand police yang diamanahkan oleh para pendiri Pesantren Benda Kerep yang kemudian menjadi konsensus bersama.

Ketiga, dalam Pengambilan keputusan yang berkaitan dengan arah kebijakan Pondok Pesantren Benda Kerep terutama dalam merespon budaya luar seperti adanya listrik, tidak dibolehkannya pesantren dan masyarakat Benda Kerep untuk menggunakan alat-alat elektronik dan komunikasi seperti TV, Radio, Telepon/HP, Pengeras suara dan lain-lain dilakukan secara kolektif oleh seluruh kyai melalui musyawarah 
mufakat. Dan Keempat, Selain mengenal kebijakan kolektif, pada prakteknya keputusan lebih sering berdasarkan pertimbangan kyai sepuh yang masih hidup yakni KH. Ahmad Faqih dan KH. Hasan. Kedua kyai sepuh tersebut merupakan cucu yang masih hidup dari Al-Maghfurlah Mbah Sholeh.

\section{Lingkungan Sosial dan Budaya Masyara- kat}

Pesantren Benda Kerep (PBK) memiliki keunikan khusus terutama dari sisi paham tradisional yang cukup kuat dan melekat di hati nurani bahkan kehidupan masyarakat, hal ini ditandai dengan pola kehidupan masyarakat yang sangat kuat dan ketat sekali berpegang teguh kepada ajaran-ajaran agama Islam. Masyarakat sekitar, khususnya Benda Kerep, merupakan bagian integral dari komunitas Pesantren (kyai dan santri). Secara kasat mata sulit sekali membedakan antara santri dan masyarakat sekitar mengingat segala kegiatan pesantren baik di bidang pendidikan maupun sosial keagamaan selalu diikuti dan didukung melalui partisipasi aktif masyarakat. Sinergitas yang terbangun selama ini menjadi modal penting bagi keberlangsungan lembaga PBK.

PBK bersama masyarakat memandang pentingnya melestarikan kearifan nilai-nilai tradisional. Oleh karena itu dalam menerima nilai modernisasi dilakukan secara selektif atas bimbingan kyai. Hal ini dilakukan sebagai langkah antisipatif terhadap dampak modernisasi. Sebagai satu contoh, hingga saat ini wilayah Benda Kerep masih belum berkenan adanya jembatan yang menghubungkan ke pesantren, walaupun beberapa kali pemerintah mencoba membantu memfasilitasi.

Santri dan masyarakat sekitar meyakini betul terhadap konsep "berkah" terhadap kyai dan pesantren. Hal ini diwujudkan dalam bentuk ketaatan terhadap wejangan dari para kyai. Beberapa santri dan warga sekitar mengaku bahwa keber- kahan itu akan muncul jika ajaran Islam dilaksanakan dengan baik melalui bimbingan kyai dan jika ada yang melanggar, mereka juga meyakini akan mendapatkan bala' kesengsaraan hidup baik di dunia maupun di akhirat.

Kegiatan haul, tahlilan, marhabanan, muludan, rajaban, nisyfu sya'ban dan syawalan merupakan tradisi keagamaan yang senantiasa dilestarikan dan dilaksanakan oleh PBK dan masyarakat Benda Kerep hingga sekarang. Sifat kekeluargaan dan saling tolong-menolong serta menghormati kyai dan keturunannya serta orang yang lebih tua merupakan budaya yang senantiasa diamalkan oleh masyarakat Benda Kerep.

Demikian pula budaya menutup aurat juga sangat ditekankan. Pakaian adat (sarung dan kopiah) dan busana muslimah (jilbab) merupakan pakaian yang wajib tidak hanya dalam kegiatan shalat dan mengaji. Sarung dan kopiah (bagi laki-laki) dan jilbab bagi perempuan tidak hanya dipakai oleh santri, tetapi oleh seluruh masyarakat Benda Kerep dari anak-anak sampai orang tua, bahkan para tamu yang datang (tidak membawa sarung dan kopiah) disediakan fasilitas sarung dan kopiah di masjid pesantren.

\section{Program Pendidikan}

Program pendidikan yang diterapkan di PBK hingga saat ini terlihat masih mempertahankan tradisi salafiyah. Selain mempelajari al-Qur'an, kitab kuning merupakan teks yang dipelajari para santri. Tidak dijumpai teks penunjang lainya selain kitab kuning. Program pendidikan pesantren yang diterapkan di PBK sejak berdiri hingga sekarang tidak menggunakan sistem madrasi (klasikal) formal. Meski demikian, kitab yang sedang dikaji oleh suatu kelompok santri menandakan tingkatan santri tersebut. Dengan kata lain, tingkatan santri dibedakan berdasarkan kitab yang sedang dikaji. Sebagai contoh dalam kajian fiqih, bagi santri pemula diajarkan kitab dasar 
yang sudah tidak asing lagi yakni kitab Safiinatunajah. Setelah selesai, untuk tingkat menengah dilanjutkan dengan kitab Fathul Qoriib, setelah itu dilanjutkan kajian kitab Fathul Mu'in, Fathul Wahab, Iqna dan seterusnya. Untuk ilmu alat misalnya, bagi santri pemula diajarkan kitab al-Jurumiyyah, diteruskan dengan kitab 'Imrithi, kemudian kitab Alfiyyah Ibnu Malik dan seterusnya. Dalam bidang Tafsir, kitab yang diajarkan adalah Tafsir Jalalain, Tafsir Munir. Dalam bidang akhlak beberapa kitab yang diajarkan adalah Ta'limul Muta'allimin, Muroqi, Mu'awanah, Tanwirul Quluub, Ihya Ulumuddin, dan Hikam. Program pendidikan bagi santri putri, selain kajian kitab di atas juga ditambah dengan materi kitab kuning yang berkaitan dengan masalah kewanitaan seperti kitab al-Adab al-Mar'ah, 'Uquudulujain, Masaailunnisa, dan lain-lain.

Selain itu, pada bulan suci Ramadhan, sebagaimana lazimnya budaya pesantren lainnya, PBK mengadakan pengajian umum yang biasa disebut dengan istilah "pasaran/kilatan" biasanya dilakukan selama 20 hari. Kemudian pada bulan Rabi'ul Awwal dilakukan pengajian kilat/pasaran selama 8 hari. Program pendidikan semacam short course ini tidak hanya diikuti para santri, tetapi terbuka untuk seluruh masyarakat umum.

Sistem metode pembelajaran yang dilakukan selama di PBK adalah metode sorogan, bandongan, halaqoh. ${ }^{7}$ Menurut Ky.

${ }^{7}$ Sorogan artinya belajar secara individual dimana seorang santri berhadapan dengan seorang guru/kyai, terjadi saling interaksi saling mengenal diantara keduanya.), Bandongan adalah belajar sevcara kelompok yang didikuti oleh seluruh santri. Biasanya kyai/ustad menggunakan bahasa daerah setempat dan langsung menerjemahkannya kalimat demi kalimat dari kitb yang dipelajarinya. Halaqoh adalah diskusi untuk memahami isi kitab, bukan untuk memepertanyakana kemungkinan benar atau salahnya apa-apa yang diajarkan oleh Kitab, tetapi untuk memahami apa maksud yang diajarkan oleh Kitab. Santri yakin bahwa Kyai tidak akan mengajarkan hal-hal yang salah, dan merka juga yakin bahwa isi kitab yang dipelajari adalah benar (Mastuhu. 1994. Dinamika Sistem Pendidikan Peantren: suatu Kajian
Miftah, Metode sorogan paling diutamakan karena dengan metode ini antara kyai dan santri dapat berinteraksi langsung lebih mendalam, sehingga memungkinkan diantara keduanya mempunyai ikatan emosional yang kuat dan kyai dapat mengetahui seberapa jauh kemampuan dari masingmasing santri yang dibimbing. Selain itu diharapkan santri dapat melatih mental membaca kitab baik saat masih menjadi santri maupun saat di luar pesantren/masyarakat. $^{8}$

Kitab-kitab yang diajarkan dengan metode sorogan adalah kitab-kitab yang dari segi jumlah halamannya tidak terlalu tebal -seperti kitab Tijan Darore, Safinatunnajah, al-Jurumiyyah-- sehingga tidak membutuhkan waktu yang lama, sedangkan metode bandongan biasanya kitab-kitab yang diajarkan dari segi jumlah halamannya lebih banyak - seperti kitab Fathul Muin, Al-fiyah Ibnu Malik, Tafsir Jalalain, Ihya Ulumuddin, dan lain-lain.

Menurut KH. Miftah, pemilihan namanama kitab yang akan diajarkan umumnya berdasarkan keinginan dan kemauan santri sendiri. Hal ini nampak dalam pengamatan pada setiap pengajian, baik sorogan maupun bandongan para santri bebas memilih kitab yang akan dikaji. Walaupun demikian, kyai tetap memberikan pertimbangan dan arahan yang apa semestinya dilakukan para santri dalam mempelajari kitab kuning.

Baik sorogan maupun bandongan, pelajaran yang disampaikan dalam bahasa Jawa dan juga dijelaskan dalam bahasa campuran Jawa-Indonesia. Para santri secara cermat mengikuti penjelasan-penjelasan yang diberikan oleh kyai dengan memberikan catatan-catatan tertentu pada kitabnya masing-masing dengan kode-kode tertentu pula, sehingga kitabnya disebut kitab jenggot, karena banyaknya catatana-cataatan

tentang Unsur dan Nilai Sistem Pendidikan Pesantren. Jakarta: INIS, h. 61).

${ }^{8}$ Hasil Wawancara dengan K. Miftah, di Rumahnya, Tanggal 23 September 2011. 
yang meyeruapai jenggot. Kyai menerjemakan kitab secara kata demi kata, atau kalimat demi kalimat dari isis kitab dalam bahasa Jawa, tidak ada tanya jawab. Dengan teknik bandongan kyai tidak mengetahui secara individual siapa-siapa santri yang datang mengikuti pengajian. ${ }^{9}$

Para santri juga diajarkan keterampilan sebagai bekal kemandirian seperti, cara bertanam / bertani (bagi santri putra) dan memasak / membuat kue bagi santri putri, ada juga pembekalan secara fisik seperti ilmu bela diri/pencak silat bagi santri yang sudah lama dan akan keluar pesantren.

Selain rutinitas pengajian harian, PBK juga menyelenggarakan acara tahunan yang melibatkan santri dan masyarakat Benda secara luas. Acara ini antara lain Muludan, Khaul dan Syawalan. Kegiatan Muludan biasanya dilaksanakan oleh santri bersama masyarakat bertepatan dengan tanggal 12/13 Maulud (bulan Rabi'ul Awal) pada setiap tahunnya. Dengan memperingati hari besar nabi Muhammad SAW, mereka berharap mendapatkan keberkahan baik hidup di dunia ataupu di akhirat kelak, atau paling tidak dapat menjadikan perilaku Nabi Muhammad sebagai suri tauladan bagi umatnya. Berbeda dengan kegiatan Khaul. Khaul biasanya dilaksanakan setiap tanggal 11,12 dan 13 Dzulhijjah, maksud perayaan ini dilaksanakan adalah untuk memanjatkan doa bersama dalam rangka mengirim fatihah atau doa kepada khususnya pendiri atau sesepuh PBK yang sudah meninggal dunia, dengan harapan dapat keberkahan dari kyai sepuh yaitu KH. Mbah Sholeh, KH. Mbah Muslim, dan KH. Mbah Abu Bakar, serta umumnya pendiri PBK. Sedangkan kegiatan Syawalan dilakukan komunitas PBK pada setiap tanggal 08 Syawal.

${ }^{9}$ Mastuhu, Mastuhu, 1994. Dinamika Sistem Pendidikan Peantren: suatu Kajian tentang Unsur dan Nilai Sistem Pendidikan Pesantren. Jakarta: INIS, h. 145

\section{Santri dan Tenaga Pengajar}

Jumlah santri di PBK saat ini berjumlah sekitar 240 santri putra dan putri yang mukim. Jumlah santri tersebar di rumah-rumah atau asrama kyai masing-masing. Diantara kyai yang merupakan anak menantu keturunan Mbah Sholeh yang berdomisili di Benda Kerep adalah; KH. Ahmad Faqih, KH. Hasan, KH. Ahmad Muharror, KH. Abdullah, KH. Muhammad, KH. Amsor, KH. Miftah, KH. Isma'il, KH. Munir, Kyai Kholil dan Kyai Ahmad Mubarok. Adapun untuk santri putri, selain diajar oleh para kyai di atas juga dibimbing oleh para Nyai (isteri kyai).

Selain santri mukim yang berasal dari berbagai wilayah yang menetap di pondok, terdapat juga santri kalong, yaitu santri yang belajar mengaji pulang dan pergi, karena mereka tinggal dan berasal dari lingkungan sekitar pesantren. Jumlah santri kalong yang belajar tidak banyak seperti santri yang mukim.

Dilihat dari lamanya santri belajar di pesantren, dikenal istilah santri junior (santri yang masih baru belajar), dan santri senior (santri yang sudah lama belajar sekitar tiga tahun ke atas). Selain itu, dalam komunitas santri juga dikenal istilah "rencang" atau abdi dalem atau khadim-nya para kyai. Pada umumnya kyai memiliki rencang yang bertugas mengabdi, melayani dan membantu keperluan hidup kyai. Tugas mereka ada yang di dalam rumah kyai, seperti melayani dan membantu keperluan kyai, ada juga rencang yang bertugas di luar rumah/ pesantren seperti memelihara kebun atau sawah milik kyai. Para santri yang menjadi rencang dipilih berdasarkan penunjukkan langsung dari kyai dan biasanya mereka adalah para santri senior yang sudah lama belajar/nyantri (minimal 3 tahun).

Selama mengaji/belajar di PBK, seluruh santri tidak diperkenankan "nyambi" belajar di sekolah formal. Ketentuan ini berlangsung sejak berdiri sampai sekarang. Hal ini memang orang tua santri sejak dari 
awal belajar di pesantren ini bertujuan hanya untuk belajar agama (tafaqquh fiddin) dan nantinya dapat diterapkan dalam kehidupan pribadi dan masyarakat sekitarnya.

Mayoritas santri adalah mereka yang orang tua atau familinya pernah belajar (mesantren) di PBK. Bahkan ada juga karena dapat informasi dari temannya. Dengan demikian, gambaran santri saat belajar di PBK sudah diketahui sebelumnya. Umumnya para santri berasal dari wilayah Cirebon, Indramayu, Majalengka, Kuningan, Karawang, Subang, Majalengka, Bandung, Tasikmalaya, Banten, Brebes, Tegal dan ada juga berasal wilayah luar Jawa. Dari segi usia, tidak ada batasan usia untuk menjadi santri (masuk belajar) di PBK. Secara usia, mayoritas santri adalah tamatan tingkat Sekolah Dasar, ada juga yang tamatan SLTP dan SLTA. Dari usia ini para santri secara otomatis sudah dapat membaca dan menulis latin, hal ini menjadi modal bagi para santri sehingga tidak mengalami kesulitan dalam hal mengharakati atau mensyakali kitab kuning. Selain santri yang baru belajar di pesantren ada juga yang pernah pesantren di tempat lain. Seperti diungkapkan beberapa santri (Saifullah, Tedi, Samsuddin), motivasi mereka belajar di PBK selain mendalami ilmu-ilmu keislamanan mereka juga ingin tabarukan yakni mendapatkan keberkahan dari kyai, yang dalam doktrin sufi dikenal konsep emanasi yaitu diharapkan ilmu-ilmu kyai dapat memantulkan atau memancarkan kepada santri.

Tak ada batasan waktu dalam menempuh pendidikan di PBK. Namun umumnya mereka belajar selama lima tahun bahkan lebih dari itu, untuk menentukan apakah santri sudah mampu atau belum sangat tergantung pada dawuh "restu" kyai, jika kyai belum memberikan restu walaupun sudah belajar lebih dari lima tahun, maka santri belum dengan sendirinya mengikuti apa kata kyai. Demikian juga sebaliknya, walaupun baru belajar kurang dari lima tahun, tetapi kyai memberikan restu maka santri dapat keluar menegmbangkan ilmu- nya atau belajar ke lembaga pendidikan lainnya.

Biaya syahriyah (bulanan) santri setiap bulanya dikenakan biaya Rp. $15.000,-$. Biaya tersebut digunakan untuk keperluan santri sendiri seperti biaya listrik dan biaya kebutuhan lainnya. Sedangkan biaya hidup diserahkan pada santri masing-masing. Umumnya setiap bulan orang tua mereka datang ke pesantren untuk membawa bekal bulanan, ada juga mereka yang dikirim melalui teman satu pondok.

Selama ini kegiatan proses belajar mengajar (mengaji), tenaga pengajarnya adalah para kyai dan anak menantunya serta nyai (bagi santri putri). Proses pendelegasian mengajar bagi santri senior untuk mengajar santri pemula, dilakukan secara insidensial, seperti jika kyai berhalangan ada kegiatan di luar. Dengan kata lain, transformasi intelektual para santri dilakukan secara langsung oleh para kyai, hanya sesekali saja jika kyai berhalangan mengajar maka didelegasikan kepada santri senior.

Latar belakang pendidikan tenaga pengajar (kyai), selain belajar di Pesantren Benda Kerep, mereka juga pernah belajar di pesantren lain, pada umumnya mereka pernah belajar di Pesantren Kaliwungu, Pesantren Tegalrejo Magelang, Pesantren Lirboyo, dan beberapa pesantren yang masih ada hubungan keluarga kyai dan jaringan keilmuan pesantren. Dari pesantren-pesantren yang menjadi tempat belajar para kyai Benda terlihat ada semacam jaringan keilmuan dan thoriqoh yang perlu ditelusuri lebih lanjut.

\section{Doktrin Keagamaan dan Jaringan Intelek- tual}

Doktrin keagamaan yang diajarkan pada PBK, sebagaimana lazim di pesantren salafiyah lainya adalah konsep Ahlussunnah wal Jama'ah (Aswaja). Secara amaliah, PBK berafiliasi dengan Nahdlatul Ulama (NU), meski tak ada hubungan secara struktural. 
Kondisi demikian mengingat secara histories, Mbah Sholeh selaku pendiri pesantren merupakan sahabat dari pendiri NU, yakni Hadhratussyaikh KH. Hasyim Asy'ari.

Bentuk pemahaman keagamaan $A h$ lussunnah wal Jama'ah yang dikembangkan oleh NU disebutkan secara tegas dalam AD (Anggaran Dasar) NU Bab II tentang Akidah/Asas Pasal 3 yakni: "Nahdlatul Ulama sebagai Jam'iyyah Diniyah Islamiyyah berakidah/berasas Islam menurut faham $A h-$ lussunnah wal Jama'ah dan menganut salah satu darai madzhab empat; Hanafi, Maliki, Syafi'i dan Hambali". Untuk bidang tasawuf yang merupakan dasar pengembangan akhlak atau perilaku kehidupan individu dan masyarakat, NU menganut paham yang dikembangkan oleh Abul Qasim AlJunaidi Al-Baghdadi dan Muhammad ibnu Muhammad Al-Ghazali serta Imam-Imam yang lain. ${ }^{10}$

Oleh karena itu, doktrin keagamaan yang diajarkan di PBK meliputi akidah, fiqih dan tasawuf/akhlaq. Dalam hal akidah, sebagaimana faham NU, menganut metode Asy'ariyah dan Maturidiyah. Dalam kajian fikih, doktrin yang diajarkan adalah madzhab Syafi'i. PBK juga mengajarkan ajaran tasawuf melalui amaliah thariqah Sathoriyyah. Thariqah Sathoriyyah sendiri merupakan amaliah tharigah yang banyak dianut masyarakat wilayah III Cirebon dan termasuk salah satu Tharigah al-Mu'tabarah yang diakui oleh Nahdatul Ulama (NU).

Menurut keterangan KH. Hasan yang merupakan salah satu Kyai Sepuh PBK, amaliah thariqah yang diajarkan merupakan usaha untuk memperbaiki akhlak dan meningkatkan kualitas ibadah syaria't. Sebab antara fiqih dan tasawuf merupakan dua sisi mata uang yang tak terpisahkan, sebagaimana yang dijelaskan oleh beliau mengutip kaidah yang terkenal yaitu; Man tafaqqaha bilaa tasawwufin faqod tafassaqo, wa

${ }^{10}$ Aceng A. Aziz. 2007. Islam Ahlussunnah Waljama'ah di Indonesia ; Sejarah, Pemikiran, dan Dinamika Nahdlatul Ulama. Jakarta: Pustaka Ma'arif NU, h. 15 man tasawwafa bilaa tafaqquhin faqod tazandaqo. "Barang siapa yang mengamalkan fiqih tanpa dibarengi tasawuf, maka sungguh ia telah berbuat fasik (rusak), dan barang siapa bertasawuf tanpa fiqih maka ia akan menjadi zindiq. ${ }^{11}$

\section{Pelelestarian dan Perubahan Orientasi Pe- santren}

\section{Periode Salafiyah Murni}

PBK, sebagaimana umumnya pesantren pada periode awal dipelopori oleh tokoh kharismatik bahkan heroik. Pendiri pesantren ini adalah Al-Maghfurlah Mbah Sholeh, diteruskan oleh generasi berikutnya. Ada beberapa hal penting yang terdapat di PBK pada perode ini, yaitu antara lain:

a. Selain mempelajari Al-Qur'an, secara takhassus hanya mempelajari literatur klasik (kitab kuning) yang berfaham Ahlussunnah waljama'ah;

b. Pendidikan akhlakul karimah merupakan hal pelajaran yang paling mendasar;

c. Seorang kyai secara langsung mendidik dan membimbing semua santri tanpa dibedakan tingkatan santri tersebut;

d. Amaliyah thariqah diberikan kepada setiap santri yang sedang menuntut ilmu dengan harapan akan terbentuk kesalehan ritual dan kesalehan sosial secara lebih baik;

e. Tidak ada pembedaan terhadap santri pemula dengan santri senior (yang lebih dulu mesantren). Dengan kata lain suatu pengajian secara umum dapat diikuti oleh semua santri;

f. Semangat anti penjajah (pra kemerdekaan dan perjuangan pasca kemerdekaan) selalu diajarkan dalam setiap pengajian;

${ }^{11}$ Hasil Wawancara dengan KH. Hasan, Tanggal Juni 2011. 
g. Semangat anti penjajah diwujudkan dalam berbagai aspek pendidikan dan sosial kemasyarakatan seperti dalam proses belajar mengajar tidak menggunakan papan tulis karena meniru penjajah (Belanda dan Jepang) dan tidak diperbolehkannya Sekolah formal karena saat itu adanya sekolah formal merupakan salah satu politik etis dari Penjajah;

h. Kyai sepuh, merumuskan platform pesantren, sebagai wasiat kyai sepuh untuk tetap melestarikan kearifan budaya dan menolak segala bentuk budaya luar yang dapat merusak tatanan kehidupan sosial keagamaan masyarakat.

i. Wasiat atau wejangan tersebut merupakan sumber budi pekerti yang mengkristal menjadi adat istiadat bagi generasi setelahnya sekaligus menjadi guidance bagi generasi penerus.

\section{Melestarikan Tradisi Salafiyah}

PBK saat ini dipimpin oleh generasi ketiga. Kyai sepuh yang masih hidup dan berdomisili di Benda Kerep yakni KH. Ahmad Faqih dan KH. Hasan. Saat ini sistem pendidikan PBK tidak mengalami perubahan signifikan dari periode salafiyah murni sebelumnya. Tradisi salafiyah dan sistim pendidikan PBK hingga sekarang masih tetap dipertahankan. Apa yang berlangsung di PBK seolah-olah merupakan gambaran pendidikan pesantren periode-periode awal dimana semua santri dengan pakaian sarungnya ngaji secara wetonan dan sorogan, tradisi pesantren yang masih dilestarikan dan menjadi ciri khas PBK. Bahkan lebih unik lagi, sarung dimaknai sebagai sorbannya Sunan Gunung Jati.

Secara sosial, setiap kebijakan yang mengarah kepada perubahan dilakukan penuh kehati-hatian dengan berpedoman pada Al-maslahah Al-Mursalah dan tetap menimbang bobot dampak mafsadat-nya. Seperti masuknya jaringan listrik di wila- yah Benda Kerep sekitar 15 tahun yang lalu merupakan bukti masyarakat pesantren ini tetap menerima unsur perubahan. Meski demikian tetap meminimalisir dampak tersebut dengan tetap melarang seluruh komunitas pesantren dan masyarakat Benda Kerep untuk menggunakan alat-alat elektronik seperti TV, radio, telepon/ handphone dan pengeras suara bahkan koran sebagai antisipatif terhadap pengaruh arus modernisasi yang dapat merusak nilai-nilai budaya lokal.

Hingga saat ini pun, ketatnya proteksi terhadap hal yang datang dari luar masih sangat kentara, sebut saja misalnya sekedar ingin dibangunkan jembatan saja mereka menolak. Praktis, untuk menuju wilayah Benda Kerep kendaraan tidak bisa masuk dan akses satu-satunya adalah dengan menyeberangi sungai bebatuan yang cukup lebar sekitar 80 meter. Jika kondisi sungai banjir, maka harus menunggu surut terlebih dahulu. Diantara alasan logis masih belum diperkenkannya membangun jembatan menurut K. Miftah bahwa selain adanya wasiat dari Mbah Soleh bahwa kehadiran jembatan akan menimbulkan lintas budaya lokal dan interlokal, lagi pula akan menimbulkan kebisingan dari alat transportasi itu jelas mengganggu ketenangan dan kekhusuan belajar para santri dan masyarakat setempat. K. Mifah juga menjelaskan walaupun ada manfaatnya dengan adanya jembatan, tetapi lebih banyak mudharatnya. Beliau menggunakan kaidah dar'ul mafaasid muqaddamun 'ala jalbil mahsaalih. Dari ungkapan ini dimaknai, bahwa larangan ini pada awalnya merupakan sebuah metode untuk menentang segala bentuk penjajahan kolonial Belanda seperti dalam hal sistem pendidikan dan apa yang menyerupai penjajah. Selanjutnya, kaidah ini menjadi keyakinan yang terus dilestarikan oleh generasi keturunan pendiri saat ini. Seiring dengan perubahan yang terjadi, larangan itu hanya berlaku di lingkungan pesantren Benda Kerep saja, tetapi bagi 
santri, setelah keluar dari PBK, kaidah itu kelihatannya tak berlaku lagi.

Perubahan yang terjadi pada periode ini, terutama dalam aspek pendidikan pesantren, lebih kepada cara pandang yang lebih kooperatif selektif dalam menghadapi pangaruh luar. Meski sampai saat ini pesantren tidak mengadakan pendidikan formal, bagi santri yang sedang menuntut ilmu, tetapi tidak melarang santri yang sudah menjadi alumni untuk melanjutkan ke pendidikan formal. Meski tidak mendapatkan pendidikan formal, masyarakat PBK banyak yang tetap bisa membaca, menulis dan menghitung dengan baik. Pendidikan ini diajarkan secara informal oleh orang tua di rumah masing-masing, dan ada juga anak kyai yang belajar membaca dan menulis latin bersama para santri yang memang sudah dapat membaca tulis latin (karena umumnya para santri adalah tamatan SD sampai SMA).

\section{Pendidikan Berbasis Kitab Kuning}

Dipelopori oleh kyai-kyai muda PBK, pengajaran kitab kuning di PBK dilakukan secara berjenjang, mulai dari kitab-kitab rendah kemudian naik ke kitab yang lebih tinggi. Melalui methode berjenjang ini diharapkan proses pengajian santri lebih fokus dan terarah. Selain itu juga diadakan kegiatan diskusi (bahtsul masail) yang dilakukan para santri setiap minggu yang sebelumnya belum pernah ada. Kegiatan ini menambah wawasan tersendiri bagi kalangan santri, dimana dalam kegiatan tersebut para santri membedah dan mendiskusikan suatu persoalan-persoalan dengan merujuk pada kitab-kitab kuning.

Berkaitan dengan penguatan adaptasi dan prespektif PBK terhadap pengembangan metodologi pendidikan, pada fase ini dapat dijelaskan beberapa hal berikut: Pertama, Perubahan yang terjadi lebih pada cara pandang PBK dalam menghadapi perubahan yang terjadi secara selektif antisipatif. Kedua, Dalam memandang pen- tingnya pendidikan formal, generasi muda kyai PBK, seperti yang diungkapkan oleh KH. Miftah, pada dasarnya pendidikan formal adalah penting, hanya saja selama menjalani pendidikan di PBK, santri belum diizinkan untuk menempuh pendidikan formal. Ketiga, KH. Miftah, MA merupakan pioneer yang lebih akomodatif dalam menerima perubahan dengan tetap teguh berpijak pada tradisi. Beliau merupakan satu-satunya keturunan Al-magfrulah Mbah Sholeh yang berdomisili di Benda Kerep yang mengenyam pendidikan formal sampai S2. Satu hal yang menarik, KH. Miftah, MA, selain menimba ilmu di berbagai pesantren salaf seperti Kaliwungu, beliau juga menamatkan kuliah di UNISULA Semarang. Selama kuliah sampai wisuda S1, tidak ada satupun kalangan pesantren yang mengetahui, termasuk ayah beliau yakni KH. Faqih. Ketika KH. Faqih mengetahui anaknya kuliah, pada awalnya beliau sempat kecewa, tetapi $\mathrm{KH}$. Miftah dapat memberikan argumen yang rasional, bahkan beliau diizinkan melanjutkan kuliah S2 di Universitas Terbuka (UT) Pondok Cabe sampai memperoleh gelar magister. Beliau beralasan tidak ada dikhotomi ilmu, meski ilmu agama adalah yang lebih utama, pendidikan formal yang didapat tidak lebih sebagai upaya tholabul 'ilmi. Oleh karenanya beliau lebih memilih mengabdikan kepada pesantren dan masyarakat daripada menjadi abdi negara (menjadi PNS), terlebih sebagai politikus.

Meski jejak KH. Miftah, MA belum diikuti oleh keturunan Pesantren yang berdomisili di Benda Kerep, namun kondisi ini mengindikasikan bahwa pada dasarnya Pesantren Benda Kerep tidak "alergi" terhadap pendidikan formal. Hanya saja selama santri mengikuti pendidikan di Pesantren Benda Kerep tetap tidak diizinkan "nyambi" mengikuti pendidikan formal dengan maksud agar lebih fokus melaksanakan tafaqqahuu fi al-diin. 


\section{Mobilitas Alumni Pesantren}

Kehadiran pesantren tidak terlepas dari harapan dan persepsi masyarakat sebagai penggunanya. Harapan dan persepsi masyarakat semakin kuat terhadap keberadaan pesantren maka lembaga pesantren akan semakin kokoh di tengah-tengah masyarakat. Salah satu yang menjadi penopang eksisitensi pesantren adalah kemampuannya dalam melahirkan output/ alumni pesantren yang memiliki peran dan kontribusi bagi masyarakat yang dilayani. Mobilitas alumni inilah yang membawa efek positif bagi keberadaan pesantren ke depannya.

Tidak ada data pasti dan tertulis mengenai jumlah output (alumni) yang dihasilkan PBK. Menurut KH. Miftah, jumlahnya sudah mencapai ribuan, mengingat usia pesantren yang sudah ratusan tahun. Pada periode awal, basis alumni PBK lebih banyak berkiprah sebagai ulama yang secara khusus mengabdi dan mengembangkan syiar Islam di masyarakat. KH. Habib Lutfi Pekalongan dan Habib Abu Bakar adalah salah satu ulama kharismatik yang tercatat sebagai alumni PBK.

Pada perkembangan selanjutnya, secara umum, sebagaimana pada pesantren lainnya, alumni PBK menempati beberapa aktifitas diantaranya: pertama, secara takhassus melanjutkan pendidikan non formal (mesantren) pada lembaga pendidkan pesantren lain seperti Pesantren Kaliwungu, Tebuireng Jombang, Lirboyo dan lain-lain. Kedua, melanjutkan pendidikan formal seperti ke Perguruan Tinggi dan lain-lain. Ketiga, melanjutkan ke lembaga pesantren lain sekaligus menempuh pendidikan formal. Keempat, dikenal dengan istilah "alumni mukim" yaitu alumni PBK yang siap terjun melakukan pengabdian kepada masyarakat. Kelima, banyak alumni PBK juga yang mengembangkan wirausaha seperti menjadi pedagang kain, karpet dan lain-lain yang tersebar di Cirebon, Tasika- malaya, Bandung, Jakarta (Tanah Abang), dan lain-lain.

Saat ini PBK secara informal, menjalin kerja sama dengan IAIN Syekh Nurjati Cirebon dengan mengirimkan alumni yang berminat untuk melanjutkan pendidikan kuliah. Meskipun banyak santri yang tidak memiliki ijazah formal (SLTP dan SLTA), kerjasama ini tetap dimungkinkan karena IAIN Syekh Nurjati Cirebon mengeluarkan kebijakan, bagi santri yang bisa membaca kitab kuning dan menghafal beberapa juz al-Qur'an tetap bisa melanjutkan kuliah di IAIN Syekh Nurjati.

\section{PENUTUP}

\section{Kesimpulan}

1. PBK merupakan salah satu pesantren yang secara konsisten melaksanakan peran-peran mempertahankan, melanggengkan, melestarikan (al muhafadhatu alal qadiimi shalih) terhadap tradisi dan sistim pendidikan salafiyah. Orientasi pendidikannya lebih menitikberatkan pada figh sufistik yaitu pendidikan lebih berorientasi pada penanaman nilai-nilai akhlak utama dan orientasi ukhrawi di atas duniawi. Romantisme masa lalu dan beban sejarah menjadikan PBK cenderung bersikap mempertahankan keaslian dan keunikan PBK sejak masa lampau, kini dan mungkin yang akan datang. Masyarakat sendiri dapat menerima, memanfaatkan dan menikmati keberadaan PBK baik dalam bentuk pelayanan keagamaan, pendidikan maupun peran sosial lainnya.

2. Bentuk-bentuk salafiyah kultural yang tetap eksis di pesantren salafiyah Benda Kerep berupa kegiatan Haolan, Muludan, Syawalan, Barzanzi, Tahlilan, Barkah, Manaqiban, Makbarah: tradisi tersebut terkait erat dengan kepercayaan dan ritual agama Islam dalam PBK yang sampai sekarang terus dipertahankan. Perubahan hampir tidak terjadi baik 
dalam kehidupan sosial, kultural keagamaan serta metode pembelajaran. Perubahan sistem di luar tidak serta merubah tradisi dan sistem pendidikan yang ada. Bahkan para pengasuh dengan menggunakan legitimasi wasiat para pendiri pesantren berupaya sekuat tenaga mempertahankan tradisi tersebut sebagai sebuah kelebihan dan keunikan yang justru dapat menunjang keberadaan PBK.

3. Dalam perspektif perubahan, sistem pendidikan PBK termasuk lembaga pendidikan yang "belum" sepenuhnya menerima perubahan sistem dari luar baik sebagai "as schooling" maupun sebagai "in class-room". Jaringan pendidikan yang terbangun dengan sejumlah pesantren, seyogyanya dapat mendorong terjadinya perubahan di kalangan komunitas PBK. Namun romantisme masa lalu, beban sejarah dan sebagian masyarakat yang dapat menikmati/ membutuhkan PBK, menjadikan PBK lebih bersikap mempertahankan dan melanggengkan tradisi yang ada.

\section{Rekomendasi}

1. Perlunya Pemerintah (Daerah dan Pusat) memberikan perhatian khusus, menjalin komunikasi yang baik, bantuan finansial sekaligus payung sosial lainnya terhadap PBK dengan memperhatikan lokal wisdom yang berlaku di pesantren benda.

2. Perlunya pemerintah membuka akses kepada pesantren model ini untuk memberikan penguatan jaringan kerjasama dengan lembaga lain yang mapan. Program kerjasama dengan lembaga lain yang telah mapan perlu digalakkan untuk meningkatkan mutu pendidikan, selain itu melalui kerjasama dengan lembaga yang mapan, pesantren salafiyah mendapat masukanmasukan yang berarti dan memberikan konstribusi bagi pesantren baik yang sifatnya bantuan teknis, finansial maupun kesempatan.

3. Keunikan dan kekhasan yang dimiliki PBK dalam melestarian budaya/tradisi secara turun-temurun menjadi efektif dalam membendung pengaruh budaya luar yang destrukrif, kiranya dapat dijadikan sebagai model dalam mengembangan pendidikan karakter berbasis kearifan lokal baik di sekolah maupun di masayarkat.

\section{SUMBER BACAAN}

Abbaza, Mona (1999): Pergeseran Orientasi Pendidikan Islam: Studi Kasus Alumni Al Azhar. Jakarta, LP3ES.

Anasom (2007): Kyai, Kepemimpinan dan Patronase. Semarang, Pustaka Rizki Putra.

Azra, Azyumardi (2002): Pendidikan Islam, Tradisi dan Modernisasi Menuju Millenium Baru. Jakarta, Logos.

Abdul, A. Azis, dkk. (2007): Islam Ahlussunnah Waljama'ah di Indonesia; Sejarah, Pemikiran, dan Dinamika Nahdlatul Ulama. Jakarta, Pustaka Ma'arif NU.

Dhofier, Zamakhsyari (1982): Tradisi Pesantren: Studi tentang Pandangan Hidup Kyai. Jakarta, LP3ES.

Husen, Torsten (1979): The School in Question, A Comparative Study of the School and its Future in Western Society. Oxford University Press.

Jarolimek, John (1981): The Shool in Contemporary Society: An Analysis of Social Currents, Issues, and Forces. New York, Macmillan Publishing Co.

James C. Scott. (1993): Perlawanana Kaum Tani, terj. Budi Kusworo Dkk., Jakarta, Yayasan Obor Indonesia,,

Madjid, Nurcholish (1997): Bilik-Bilik Pesantren: Sebuah Potret Perjalanan. Jakarta: Paramadina. 
Mastuhu, (1994): Dinamika Sistem Pendidikan Peantren: suatu Kajian tentang Unsur dan Nilai Sistem Pendidikan Pesantren. Jakarta, INIS

Raharjo, M. Dawam (ed.), (1985): Pergulatan Pesaantren; Membangun dari Bawah. Jakarta, P3M.

Steenbrink, Karel A. (1986): Pesantren Madrasah Sekolah Pendidikan Islam Dalam Kurun Modern. Jakarta, LP3ES
Sudjoko Prasojo, dkk., (1982): Profil Pesantren: Laporan Hasil Penelitian Pesantren al-Falak dan Delapan Pesantren Lain di Bogor. Jakarta, LP3ES.

Wahid, Abdurrahman (2001): Menggerakkan Tradisi: Esei-Esei Pesantren. Yogyakarta, LKiS. 